\title{
Section 14 StandAG - Identification of siting regions and associated challenges
}

\author{
Lisa Seidel and Marc Wengler \\ BGE mbH - Bundesgesellschaft für Endlagerung, Federal Company for Radioactive \\ Waste Disposal, 31224 Peine, Germany \\ Correspondence: Lisa Seidel (lisa.seidel@bge.de) \\ Published: 10 November 2021
}

\begin{abstract}
With the publication of the subarea interim report on sub-regions on 28 September 2020, the Federal Company for Radioactive Waste Disposal (BGE), as the implementer of the German site selection procedure, has completed the first step of phase I in due time. The second step of phase I is the identification of siting regions for surface exploration.

In the following step 2 of phase I, the determination of siting regions for surface exploration will be carried out based on the interim results of the first step of phase I in accordance with section 14 of the regulating law (StandAG). A central component of this second step of phase I is the representative preliminary safety assessments pursuant to section 27 StandAG, the ordinances on "Safety Requirements" (EndlSiAnfV) and "Preliminary Safety Assessments" (EndlSiUntV), which are carried out for each of the sub-regions. Based on the results of the preliminary safety assessments and the renewed application of the geoscientific weighting criteria (section 24 StandAG), siting regions will be identified that have the potential to become the site with the best possible safety for a repository for high-level radioactive waste. During the second step of phase I, the planning scientific consideration criteria (section 25 StandAG) can be applied for the first time.

The path to the siting regions for surface exploration can be accompanied by various challenges related to geoscientific, methodological and also societal questions. For example, the application of the representative preliminary safety assessments may be more challenging in larger subareas compared to smaller ones as subsurface properties are likely to be more variable. In this context, areas with little data coverage for example, and the treatment of these areas in the procedure may pose another challenge. Therefore, sound methodological concepts must be developed for performing the representative preliminary safety assessments as well as for applying the geoscientific weighting criteria. Furthermore, the German site selection procedure defines special requirements (section 1 StandAG): the implementation of the participatory, science-based, transparent, self-questioning and learning procedure poses challenges to all stakeholders of the procedure on the way to the best possible disposal of high-level radioactive waste.
\end{abstract}

Kurzfassung. Mit der Veröffentlichung des Zwischenbericht Teilgebiete am 28. September 2020 hat die BGE als Vorhabenträgerin des deutschen Standortauswahlverfahrens den Schritt 1 der Phase I abgeschlossen. Der zweite Schritt der Phase I beinhaltet die Identifizierung von Standortregionen für die übertägige Erkundung.

Im folgenden Schritt 2 der Phase I erfolgt die Ermittlung der Standortregionen für die übertägige Erkundung auf Grundlage der Zwischenergebnisse des Schritt 1 der Phase I gemäß § 14 StandAG. Zentraler Bestandteil dieses Schritt 2 der Phase I sind die repräsentativen vorläufigen Sicherheitsuntersuchungen nach $\S 27$ StandAG, der Endlagersicherheitsanforderungsverordnung (EndlSiAntV) und der Endlagersicherheitsuntersuchungsverordnung (EndlSiUntV), die für jedes der Teilgebiete durchgeführt werden. Auf der Grundlage der Ergebnisse der repräsentativen vorläufigen Sicherheitsuntersuchungen und der erneuten Anwendung der geowissenschaftlichen Abwägungskriterien ( $\$ 24$ StandAG) werden günstige Standortregionen ermittelt, die das Potenzial haben, derjenige Standort mit der bestmöglichen Sicherheit für ein Endlager für hochradioaktive Abfälle zu werden. Im Schritt 2 der Phase I können erstmals die planungswissenschaftlichen Abwägungskriterien (§ 25 StandAG) angewendet werden. 
Der Weg zu den Standortregionen für die übertägige Erkundung ist mit verschiedenen Herausforderungen verbunden, die geowissenschaftliche, methodische und auch gesellschaftliche Fragen betreffen. So kann die Anwendung der repräsentativen vorläufigen Sicherheitsuntersuchungen in größeren Teilgebieten schwieriger sein als in kleineren, da die Eigenschaften des Untergrunds variabler sein könnenn. In diesem Zusammenhang können z. B. Gebiete mit geringerer Datenabdeckung eine weitere Herausforderung darstellen. Für die Durchführung der repräsentativen vorläufigen Sicherheitsuntersuchungen sowie für die Anwendung der geowissenschaftlichen Abwägungskriterien müssen daher fundierte methodische Konzepte entwickelt werden. Darüber hinaus stellt das deutsche Standortauswahlverfahren besondere Anforderungen (§ 1 StandAG) an die Durchführung des partizipativen, wissenschaftsbasierten, transparenten, selbsthinterfragenden und lernenden Verfahrens und stellt alle Verfahrensbeteiligten vor Herausforderungen auf dem Weg zur bestmöglichen Entsorgung hochradioaktiver Abfälle.

Acknowledgements. Too many colleagues have and will contribute to the process of nuclear waste site selection to be named here as abstract authors; however, their contributions are most important and valued.

\section{References}

StandAG: Standortauswahlgesetz vom 5. Mai 2017 (BGBl. I S. 1074), das zuletzt durch Artikel 1 des Gesetzes vom 7. Dezember 2020 (BGB1. I S. 2760) geändert worden ist.

EndlSiAnfV: Endlagersicherheitsanforderungsverordnung vom 6. Oktober 2020 (BGB1. I S. 2094).

EndlSiUntV: Endlagersicherheitsuntersuchungsverordnung vom 6. Oktober 2020 (BGB1. I S. 2094, 2103). 